\title{
The Diagnosis of Online Game Addiction on Indonesian Adolescent Using Certainty Factor Method
}

\author{
Kundharu Saddhono*, Bagus Wahyu Setyawan, Yusuf Muflikh Raharjo, Rio Devilito \\ Graduate School of Javanese Language and Literature, Faculty of Teacher and Training, Universitas Sebelas Maret, Surakarta, \\ 57126, Indonesia
}

Corresponding Author Email: kundharu_s@staff.uns.ac.id

https://doi.org/10.18280/isi.250206

Received: 2 December 2019

Accepted: 19 February 2020

\section{Keywords:}

game online addiction, Indonesian adolescent, certainty factor method, expert system

\begin{abstract}
This research discusses about online games which become ones of the most popular commodities, particularly among adolescents. It is suggested that they prefer spending time by playing online games to studying. Consequently, the phenomenon of online game addiction gets significant. The study aimed to explain and describe the use of Certainty Factor Method with expert system to diagnose online game addiction on adolescents. Its setting was Java island by involving some students as subject of the study. Survey method was employed to obtain the data while its instrument in terms of questionnaire was provided in Google forms and distributed to the students. An interactive qualitative approach was deployed to analyze the data combined with certainty factor method to show the level of game online addiction. The result shows from the sample of data which have analyzed addiction level toward online games is relatively moderate. Most of the users are adolescents between 12 and 15 years old and spend about 4 until 6 hours in a day. This condition becomes worse if there is no treatment for adolescents. Hence, there is a need of parents' control and awareness toward children's activity in playing online games since it renders negative impacts particularly on children's learning activity and motor development.
\end{abstract}

\section{INTRODUCTION}

Technology increasingly and immensely develops over time. The fast development of information transmission with the employment of the internet becomes one of the factors the computer technology is distributed to isolated areas despite in developing countries $[1,2]$. This situation is undeniable since computer technology has distributed within mostly aspects of human life such as lifestyle, basic necessities, human appliances, and entertainment. Besides, the use of electronic devices in human daily activities also contributes to socially, economically, and culturally changing human behavior. Moreover, human life becomes more developed and modern and results in the borderless world [3]. On the other hand, in this era, the industry revolution 4.0 era, the computer technology becomes a partner for modern people [4]. The survey conducted by Association of Indonesian Internet Providers (APJII) in 2015 showed the increase in internet usage from 2005 to 2014. In 2014, it reflected 88.1 million users, rising 71.2 million from the previous year. The majority of internet users in Indonesia is occupied by people in western areas, particularly Java Island, reaching $36.9 \%$ from the total population. Besides, $83.5 \%$ internet users reside in urban areas [5].

One of the most popular internet-based computer technologies is online games. It is a digitized game rapidly existing in this modern era. While some people think that online games are identically related to the computer, they are exactly able to be operated in other devices. They are console, handled, and cell phone $[6,7]$. At the present time, there are many online games with an online community feature, and this feature simultaneously becomes a social activity. As a consequence, online games are more popular than single player games since they give more challenges and satisfaction. This type of game is known as Massively Multiplayer Online Games (MMOG). They provide a hundred to thousand players to play the game concurrently (with internet access) [8]. There are some types of MMOG, including Massively Multiplayer Online Role Playing Game (MMORPG), i.e. Ragnarok and Seal; Massively Multiplayer Online Real Time Strategy (MMORTS), i.e. League of Legends, Dota 2 and Warcraft; and Massively Multiplayer Online First Person Shooter (MMOFPS), i.e. Counter Strike, Point Blank, Ricing Force, and Perfect Wars.

Players of these online games are mostly adolescents. Since the majority of internet users in Indonesia are between 18 and 25 years old, and $49 \%$ amongst the total internet users are online game players. It indicates that the segment of internet users in Indonesia includes those categorized as 'digital native'. Digital natives are generation, born after 1980 when digital social media technologies such as Usenet and Bulletin Board System were established [9]. In 2016, Indonesian adolescents' activity in playing a game or downloading a video game is around $44.10 \%$, and adolescents between 10 and 24 years old are $18.4 \%$ amongst the total population [10]. The prevalence of online game addiction on Indonesian adolescents continues to increase, and Indonesia became the sixth country with $112.6 \%$ online game addiction in 2007 . Besides, the number of online game players increases between $5 \%$ and $10 \%$ every year. 
The level of online game addiction in Indonesia tends to be high. Based on the research conducted in SMPN 13 Padang, 15 students $(11.4 \%)$ are highly addicted to online games, 60 students $(68.15 \%)$ are addicted, and 13 students $(14.75 \%)$ are less addicted. It reflects that their addiction level is medium [11]. A study conducted in the United State toward 963 adolescents between 13 and 18 years old indicates that $83 \%$ of parents feel that their children spend too much time on video games. It is in line with Malay Mail, Wednesday (22/1/2020), that $54 \%$ male play a video game for three hours or more, compared to females as much as $13 \%$ [12]. It indicates that playing a video game is the main activity for male.

In addition, the World Health Organization (WHO) includes game addiction as a disease in the report of International Classification of Disease edition 11 (ICD-11). Consequently, the game addiction is officially included as a mental health disorder. On June $18^{\text {th }}$, 2018, WHO published ICD-11 document, a revision for the previous version, ICD-10, published in 1990. This document is used by health professionals to categorize various diseases and health conditions, starting from giving a birth (JB20 Single spontaneous delivery), flu (1E32 influenza, virus not identified), and online game addiction (65C1 Gaming disorder) [13]. It is suggested that the addiction to online games becomes significant and occurs in the entire world. Moreover, it is one of the dangerous diseases as claimed by WHO. In this study, a method to diagnose online game addiction on Indonesian adolescents is proposed. It is an artificial intelligence based, known as certainty factor.

Studies on online game addiction have been conducted by some researchers. Lee \& Kim [8] discussed about phenomenon of online game addiction in Korea. Besides, Jorge \& Sibilia [14] investigated the treatment for online game addiction in Asia. Moreover, Guo \& Li [15] analyzed online game addiction with using Relapse and Time Delay model. However, those studies have not indicated the use of certainty factor method. Henceforth, this study focused on the online game addiction on Indonesian adolescents by using the certainty factor method. Although some of those studies discussed the condition of online game addiction in many countries, they only displayed the data without an effort to cope with that condition.

Accordingly, this study attempted to develop a web-based expert system used to diagnose online game addiction on adolescents in Indonesia. After getting the data about addiction level to online games, the next step was to conduct follow-up and precaution to cope with the effect of online game addiction as the worse effect was avoided. This step involved some elements, including parents, psychologist, formal education, and government regulation to cope with the phenomenon of online game addiction on adolescents in Indonesia.

\section{METHOD}

The study deployed a descriptive qualitative method with a case study approach [16]. This case study was conducted to some adolescents selected from students in Java island. It aimed to describe and explain the use of the certainty factor method in detecting online game addiction on Indonesian adolescents. The data were obtained through a survey method using google form questionnaire as the instrument. The data were analyzed using an interactive qualitative approach in combination with the certainty factor method to show the level of addiction. This research conduct by following step.

The first step was to do literature review. Literature review was conducted by collecting, reading, and understanding references related to the expert system with certainty factor method.

The second step was to collect the data from psychologists. This data was then summarized to give to online game players from online game providers. This survey was conducted by using google form, filled by gamers distributing all over Indonesia.

After obtaining the data, the next step was to describe the application being developed. This study conducted the development in terms of application program. It deployed a structured method by creating architecture, knowledge representation, and DFD (Data Flow Diagram).

1) The architecture of this system was designed to describe that this system was able to give consultation facility in diagnosing online game addiction to adolescents and getting a solution or doing a prevention to fasten healing process.

2) Knowledge representation was designed to support logical reasoning in detecting diseases appropriate with the data of symptoms included to the system.

3) Designing Database. After designing the application, the next step was to collect data for designing the database. Data inputted to the database include user, addiction, symptom, question, solution, and rule data. These data were then represented in the interrelated table [17]. They are also able to be used as supports, in terms of conclusions, facts, and rules organizing the process of data searching which are interconnected to one another. Hence, designing a database was required as a place to save those data.

4) Implementation, test, and Discussion. After the data was inputted to the database, the next step was to implement the program. In this step, the system being built was also ready to be operated. The expert system application program in diagnosing online game addiction was used as an interface with users and an inference machine to get a conclusion.

\section{RESULTS AND DISCUSSION}

\subsection{The development of expert system using certainty factor method}

Certainty factor $(\mathrm{CF})$ is a method to accommodate inexact reasoning of an expert, proposed by Shortliffe and Buchanan in $1975[18,19]$ The expert (i.e. a doctor) frequently analyzes the information using inexact reasoning. To accommodate this analysis, the expert uses certainty factor in portraying the level of the expert's belief on the problem being dealt with.

$\mathrm{CF}$ indicates the belief in an occurrence based on an evidence or expert's judgment. It uses a value to assume the level of expert's certainty on a datum. The basic formulation for $\mathrm{CF}$ is presented in the following [20].

\section{$\mathrm{CF}[\mathrm{H}, \mathrm{E}]=\mathrm{MB}[\mathrm{H}, \mathrm{E}] \mathrm{MD}[\mathrm{H}, \mathrm{E}]$}

Definition:

$\mathrm{CF}=$ certainty factor in $\mathrm{H}$ affected by $\mathrm{E}$

$\mathrm{MB}(\mathrm{H}, \mathrm{E})=$ measure of belief in $\mathrm{H}$, if $\mathrm{E}$ is given (between 0 and 1) 
$\mathrm{MD}(\mathrm{H}, \mathrm{E})=$ measure of disbelief in $\mathrm{H}$, if $\mathrm{E}$ is given (between 0 and 1)

$\mathrm{H}=$ Hypothesis

$\mathrm{E}=$ Evidence (event or fact)

An expert system mostly has more than a rule and some premises are related to AND or OR. The knowledge about premises is possibly uncertain due to the $\mathrm{CF}$ values given by patients as they answer questions from the system on the premises (symptoms) happening to the patient or the hypothesis of $\mathrm{CF}$ values [21]. Some rules for $\mathrm{CF}$ formula are shown in the following [3],

- If both $\mathrm{CF} 1$ and $\mathrm{CF} 2$ are positive: $\mathrm{CFC}=\mathrm{CF} 1+\mathrm{CF} 2 *(1-\mathrm{CF} 1)$

- If both $\mathrm{CF} 1$ and $\mathrm{CF} 2$ are negative: $\mathrm{CFC}=\mathrm{CF} 1+\mathrm{CF} 2 *(1+\mathrm{CF} 1)$

- If either $\mathrm{CF} 1$ or $\mathrm{CF} 2$ is negative: $\mathrm{CFC}=\{\mathrm{CF} 1+\mathrm{CF} 2\} /(1-\min \{|\mathrm{CF} 1|,|\mathrm{CF} 2|\})$

$\mathrm{CF}$ values are determined for each symptom corresponding in a certain disease with the range between 0 and 1 . This value represents the expert's judgment on symptoms affecting a certain disease. However, the CF method has strengths and weaknesses. The strengths are that (1) CF method is appropriate for the expert system to measure if, for example, a diagnosis of a disease is certain or uncertain, and (2) its calculation can process 2 data simultaneously, so the data accuracy is well maintained. Meanwhile, the weaknesses are that (1) the general idea of uncertainty model in human with using the numeric of CF method is usually disputed, so people will argue that the formula for CF method above has little truth, and (2) this method is only able to process uncertainty/certainty for 2 data only, so there is a need to conduct multiple processes for more 2 data of uncertainty/certainty.

\subsection{How expert system works in diagnosing online game addiction on adolescent}

The system constructed is the expert system with certainty factor method to get a conclusion in diagnosing online game addiction happening in society and its solution. This system will be constructed as an expert gets a conclusion of problems (symptoms) appropriate with his/her expertise. It will be based on Web through PHP programming with MySQL database. Before the system is operated, some data were used as the knowledge base, including symptoms, addiction level, and density level for each symptom. All knowledge bases are to give a conclusion on the diagnosis about people's addiction toward online games.

Once the consultation process is carried out, users are required to register first. Then, they login and fill the consultation form. The data inputted include username, password, sex, birthday date, and address. These data were obtained to adjust the consultation activity with the expert' or psychologist's opinion. After inputting the data and choosing questions or symptoms happening to the users, the system gives the conclusion about the type of addiction experienced by the users.

In constructing the expert system, the study determines the structure of the knowledge base. The knowledge base is a group of facts. The approach for knowledge base uses rulebased reasoning since it contains steps to achieve a solution
[22]. Some structure of this knowledge-based expert system are the followings:

1. Knowledge base of online game addiction level

2. Knowledge base of online game addiction symptoms

3. Knowledge base of value (density)

4. Knowledge base of solution

In this case, a user is able to know the level of online game addiction and its solution through inputting his/her symptoms occurring. The expert system with certainty factor method will check these symptoms with the knowledge base. It then gives the certainty value of his/her addiction level [23, 24].

The knowledge base contains addiction levels, addiction symptoms, density values, and solutions. From the data of online game addiction and its symptoms, there is a relation between symptoms and density values as indicated in Table 1.

Table 1. Symptoms and density level of online game addiction

\begin{tabular}{|c|c|c|}
\hline Code & Symptoms & $\begin{array}{l}\text { Density } \\
\text { Levels }\end{array}$ \\
\hline G1 & User frequently changes bedtime irregularly & 0.6 \\
\hline G2 & $\begin{array}{c}\text { User chooses Online Games over other } \\
\text { activities }\end{array}$ & 0.2 \\
\hline G3 & $\begin{array}{l}\text { User spends more than the normal time in } \\
\text { playing Online Games }\end{array}$ & 0.2 \\
\hline G4 & $\begin{array}{l}\text { User feels really angry about internet } \\
\text { disconnection }\end{array}$ & 0.8 \\
\hline G5 & $\begin{array}{l}\text { User is unable to be separated from hand } \\
\text { phones, tablets, PC, or other gadgets }\end{array}$ & 0.6 \\
\hline G6 & $\begin{array}{c}\text { User feels anxious and easy to get angry for } \\
\text { not playing games }\end{array}$ & 0.2 \\
\hline G7 & $\begin{array}{l}\text { User keeps a distance with own social } \\
\text { group }\end{array}$ & 0.2 \\
\hline G8 & $\begin{array}{l}\text { User lies about how long the time spent to } \\
\text { play Online Games }\end{array}$ & 0.4 \\
\hline G9 & User has a sleep disorder & 0.4 \\
\hline G10 & User has backache and neck ache & 0.4 \\
\hline G11 & $\begin{array}{l}\text { User feels happy once others ask me about } \\
\text { Games }\end{array}$ & 0.6 \\
\hline G12 & User has migraine with eye-ache & 0.2 \\
\hline G13 & User has irregular meal timings & 0.6 \\
\hline G14 & User is lack of keeping the body clean & 0.8 \\
\hline G15 & User always looks tired & 0.4 \\
\hline G16 & User has a wrist disorder & 0.2 \\
\hline G17 & Users are happy about Online Games. & 0.8 \\
\hline G18 & User understands all about Online Games & 0.4 \\
\hline G19 & $\begin{array}{l}\text { User feels proud about being level up in } \\
\text { Online Games }\end{array}$ & 0.8 \\
\hline G20 & $\begin{array}{l}\text { User is willing to queue up in the internet } \\
\text { café only for playing Online Games }\end{array}$ & 0.4 \\
\hline G21 & $\begin{array}{l}\text { Users always want to replay the same } \\
\text { Online Games despite having finished it. }\end{array}$ & 0.4 \\
\hline G22 & $\begin{array}{l}\text { User joins the community of favorite } \\
\text { Online Games }\end{array}$ & 0.4 \\
\hline G23 & $\begin{array}{l}\text { User likes idolizing the character in Online } \\
\text { Games }\end{array}$ & 0.4 \\
\hline G24 & $\begin{array}{l}\text { User has ever had a dream in becoming one } \\
\text { of the characters in Online Games }\end{array}$ & 0.4 \\
\hline G25 & $\begin{array}{l}\text { User has ever imitated the style of one } \\
\text { character in Online Games }\end{array}$ & 0.2 \\
\hline G26 & $\begin{array}{l}\text { User always looks for a new thing about } \\
\text { Online Games }\end{array}$ & 0.6 \\
\hline G27 & $\begin{array}{l}\text { User feels disappointed for being defeated } \\
\text { in Online Games }\end{array}$ & 0.6 \\
\hline G28 & $\begin{array}{l}\text { User always spends the spare time only for } \\
\text { playing Online Games }\end{array}$ & 0.4 \\
\hline
\end{tabular}




\begin{tabular}{|c|c|c|}
\hline G29 & $\begin{array}{l}\text { User always tries to play Online Games } \\
\text { better than his/her friends }\end{array}$ & 0.6 \\
\hline G30 & $\begin{array}{c}\text { User spends his/her own allowance for } \\
\text { playing Online Games }\end{array}$ & 0.6 \\
\hline G31 & User plays Online Games everyday & 0.6 \\
\hline G32 & $\begin{array}{l}\text { User is willing to use a computer in a long } \\
\text { time for playing Online Games }\end{array}$ & 0.4 \\
\hline G33 & $\begin{array}{c}\text { User is willing to skip a meal for playing } \\
\text { Online Games }\end{array}$ & 0.4 \\
\hline G34 & $\begin{array}{c}\text { User likes exploring all types of Online } \\
\text { Games }\end{array}$ & 0.4 \\
\hline G35 & $\begin{array}{l}\text { User feels something is missing for not } \\
\text { playing Online Games in a day }\end{array}$ & 0.4 \\
\hline G36 & $\begin{array}{l}\text { User prefers playing Online Games to } \\
\text { gathering with family }\end{array}$ & 0,2 \\
\hline G37 & $\begin{array}{c}\text { User prefers being friend with people who } \\
\text { like Online Games }\end{array}$ & 0.4 \\
\hline G38 & $\begin{array}{c}\text { User has ever participated to Online Game } \\
\text { Tournaments }\end{array}$ & 0.4 \\
\hline G39 & $\begin{array}{l}\text { User has an achievement in playing Online } \\
\text { Games }\end{array}$ & 0.4 \\
\hline G40 & User feels dependent to Online Games & 0.2 \\
\hline
\end{tabular}

Table 1 indicates types of the online game addiction in terms of 40 symptoms and their density values. Additionally, from the data about online game addiction and its symptoms, there is also a relation between the symptoms and levels of online addiction as represented in the following Table 2 .

Table 2. Relation between symptoms and levels of online game addiction

\begin{tabular}{cccccccc}
\hline Code & K1 & K2 & K3 & Code & K1 & K2 & K3 \\
\hline G1 & - & - & $*$ & G21 & $*$ & - & - \\
G2 & - & - & $*$ & G22 & $*$ & - & - \\
G3 & - & $*$ & - & G23 & $*$ & - & - \\
G4 & - & $*$ & - & G24 & - & $*$ & - \\
G5 & - & $*$ & - & G25 & - & $*$ & - \\
G6 & - & - & $*$ & G26 & $*$ & - & - \\
G7 & - & - & $*$ & G27 & $*$ & - & - \\
G8 & - & - & $*$ & G28 & - & $*$ & - \\
G9 & - & - & $*$ & G29 & - & $*$ & - \\
G10 & - & - & $*$ & G30 & $*$ & - & - \\
G11 & - & $*$ & - & G31 & - & $*$ & - \\
G12 & - & - & $*$ & G32 & - & $*$ & - \\
G13 & - & - & $*$ & G33 & - & $*$ & - \\
G14 & - & - & $*$ & G34 & - & $*$ & - \\
G15 & - & - & $*$ & G35 & - & - & $*$ \\
G16 & - & - & $*$ & G36 & - & - & $*$ \\
G17 & $*$ & - & - & G37 & $*$ & - & - \\
G18 & $*$ & - & - & G33 & $*$ & - & - \\
G19 & $*$ & - & - & G39 & $*$ & - & - \\
G20 & $*$ & - & - & G40 & - & - & $*$ \\
\hline
\end{tabular}

From the table

- = to show there is a symptom

\section{Description}

$=$ to show there is no symptoms

K1: Low-level Addiction to Online Game

K2: Medium-level Addiction to Online Game

K3: High-level Addiction to Online Game

The knowledge representation is used to determine the finding process or conclusion on the type of addiction based on the symptoms inputted. It is a combination between first level rule and metadata rule.

\subsection{Calculation of online game addiction with certainty factor method}

After users input the data in the system, the data about symptoms happening to them due to online games are revealed. After that, the system calculates and analyzes those symptoms using the certainty factor method, as the following case.

A user chooses some following symptoms:

1. To feel really angry about internet disconnection

2. To feel anxious and easy to angry for not playing Online Games

3. To feel happy, once others ask about Online Games

4. To feel happy about Online Games

5. To know all about Online Games

6. To feel proud about being level up in playing Online Games

7. To be willing to queue up only for playing Online Games

8. To always want to replay the same Online Game despite having finished it.

9. To be willing to skip a meal only for playing Online Games

10. To prefer playing Online Games to gathering with family

Based on the symptoms chosen, the first step is to make a rule for each Online Game addiction, as follows.

\section{Rule 1}

IF the user is happy about Online Games

AND s/he understands all about Online Games

AND s/he feels proud if s/he gets level up in Online Games AND s/he is willing to queue up in the internet café for playing Online Games

AND s/he always wants to replay the same Online Games although s/he has ever finished it

THEN she has a low-level addiction to Online Games

\section{Rule 2}

IF the user feels really angry about internet disconnection AND s/he feels happy once others ask about Online Games AND s/he is willing to skip a meal only for playing Online Games

THEN s/he has a medium-level addiction to Online Games

\section{Rule 3}

IF the user feels anxious and easy to get angry if s/he does not play Online Game

AND s/he prefers Online Games to gathering with family THEN s/he has a high-level addiction to Online Games The second step is to calculate each rule with using formula as follow:

\section{Low Addiction to Online Games}

Based on the description, $\mathrm{CF}$ values for low addiction to Online Game (K1) are G17 = 0.8, G18 = 0.4, G19 = 0.8, G20 $=0.4$, and $\mathrm{G} 21=0.4$, as the following.

$$
\begin{array}{ll}
- & \mathrm{CF}(\mathrm{A})=\mathrm{CF}(1)+[\mathrm{CF}(2) *(1-\mathrm{CF}(1)] \\
& =0.8+0.4 *(1-0.8) \\
& =0.8+0.4 * 0.2 \\
& =0.8+0.08 \\
& =0.88
\end{array}
$$

- $\mathrm{CF}(\mathrm{B})=\mathrm{CF}(3)+[\mathrm{CF}(\mathrm{A}) *(1-\mathrm{CF}(3)]$ 
$=0.8+0.88 *(1-0.8)$

$=0.8+0.88 * 0.2$

$=0.8+0.176$

$=0.976$

- $\mathrm{CF}(\mathrm{C})=\mathrm{CF}(4)+[\mathrm{CF}(\mathrm{B}) *(1-\mathrm{CF}(4)]$

$=0.4+0.976^{*}(1-0.4)$

$=0.4+0.976 * 0.6$

$=0.4+0.5856$

$=0.9856$

- $\mathrm{CF}(\mathrm{D})=\mathrm{CF}(5)+[\mathrm{CF}(\mathrm{D}) *(1-\mathrm{CF}(5)]$

$=0.4+0.9856 *(1-0.4)$

$=0.4+0.9856 * 0.6$

$=0.4+0.59136$

$=0.99136$

After getting the result, the next step is to calculate the percentage by using formula as follows.

CFcombine $* 100 \%=0.99136 * 100 \%=99.14 \%$

\section{Medium Addiction to Online Game}

Based on the description, $\mathrm{CF}$ values of medium addiction to Online Game (K2) are G4 =0.8, G11 = 0.6, and G33 = 0.4, as the following.

$$
\begin{aligned}
& \mathrm{CF}(\mathrm{A})=\mathrm{CF}(1)+[\mathrm{CF}(2) *(1-\mathrm{CF}(1)] \\
& =0.8+0.6 *(1-0.8) \\
& =0.8+0.6 * 0.2 \\
& =0.8+0.12 \\
& =0,92 \\
-\quad & \mathrm{CF}(\mathrm{B})=\mathrm{CF}(3)+[\mathrm{CF}(\mathrm{A}) *(1-\mathrm{CF}(1)] \\
& =0.4+0.92 *(1-0.4) \\
& =0.4+0.92 * 0.6 \\
& =0.4+0.552 \\
& =0.952
\end{aligned}
$$

After getting the result, the next step is to calculate the percentage using formula as the following.

CFcombine $* 100 \%=0.952 * 100 \%=95.20 \%$

\section{High Addiction to Online Game}

Based on the description in Table $1, \mathrm{CF}$ values of high addiction to online games $(\mathrm{K} 3)$ are $\mathrm{G} 6=0.2$ and $\mathrm{G} 36=0.2$, as the following.

$$
\begin{array}{ll}
- & \mathrm{CF}(\mathrm{A})=\mathrm{CF}(1)+[\mathrm{CF}(2) *(1-\mathrm{CF}(1)] \\
& =0.2+0.2 *(1-0.2) \\
& =0.2+0.2 * 0.8 \\
& =0.2+0.16 \\
& =0.36
\end{array}
$$

After getting the result, the next step is to calculate the percentage using formula as the following:

$$
\text { CFcombine } * 100 \%=0.36 * 100 \%=36 \%
$$

After conducting the test on the sample in Java Island, it shows the following result. Table 3 shows the data of respondent characteristic of online game addiction level $(\mathrm{N}=$ 150).

Table Respondent Characteristic of Online Game Addiction Level $(\mathrm{N}=150)$
The table indicates that online game users are mostly between 12 and 15 years old, reflected by $50 \%$ users amongst the total sample. Besides, male is more dominant in playing games compared to female, which are 110 male respondents or $73.3 \%$. Meanwhile, the users usually spend 4 to 6 hours in a day with reference to $32 \%$ choices amongst the total respondent and $59.3 \%$ users use hand phones to play online games. Based on this result, it reflects that most students of online game users are between 12 and 15 years old or junior high school students. This is because of that they look for their identity and are still labile [25]. Additionally, adolescents are not much busy, so they spend their spare time playing online games for 4 to 6 hours in a day. They mostly carry it out in their house after school or at nighttime. They claim that 4 to 6 hours are the ideal duration in playing online games unless they feel dissatisfied [26]. As a consequence, educating gadget users among the young generation, especially students, is required. These efforts are to minimize negative impacts of the technology development toward students' learning results. Besides, teachers are able to use some teaching methods in combination with smartphone usage such as Edmodo, schoology, and other e-learning applications to educate students in wisely using gadgets.

Table 3. Data result of test

\begin{tabular}{cccc}
\hline \multirow{2}{*}{ Respondent Characteristics } & \multicolumn{2}{c}{ Result } \\
\cline { 2 - 4 } & & $f$ & $\%$ \\
\hline Age & $10-12$ years old & 30 & 20 \\
& $12-15$ years old & 75 & 50 \\
& $15-18$ years old & 45 & 30 \\
\hline Sex & Male & 110 & 73.3 \\
& Female & 40 & 26.7 \\
\hline Duration & $<1$ hour & 11 & 7.3 \\
& $1-2$ hours & 30 & 20 \\
& $2-4$ hours & 36 & 24 \\
& $4-6$ hours & 48 & 32 \\
& $>6$ hours & 25 & 16.7 \\
\hline Place & House & 97 & 64.7 \\
& Internet Café & 16 & 10.7 \\
& Everywhere & 40 & 24.6 \\
\hline Device & Computer & 35 & 23.3 \\
& Laptop & 16 & 10.7 \\
& Handphone & 89 & 59.3 \\
& Others & 10 & 6.7 \\
\hline
\end{tabular}

\section{CONCLUSIONS}

After analyzing the data on 200 samples of Indonesian adolescents as online game users, it was found that the level of addiction level to online games was at medium level. However, some numbers showed the high level. By using the certainty factor method, it was indicated that most online game users in Indonesia were between 12 and 15 years old or junior high school (SMP) students. Besides, the average duration they spent in playing online games were between 4 and 6 hours per day to get satisfaction. In general, the certainty method factor was able to be used in diagnosing online game addiction on adolescents in Indonesia. It was due to the expert system developed employed artificial intelligent (AI) technology combined with the expert system as the representation of a psychologist. The outputs of this study were in terms of addiction and symptom data from adolescents as online game users. The next step, the researchers will collaborate with related institutions such as formal education, parents, 
stakeholders in TI, and Indonesian Children Protection Commission (KPAI) to make strategic steps and treatments possibly used for coping with online game addiction on adolescents in Indonesia. The researcher expects that Indonesian adolescents will be wiser in playing online games and avoid playing online games if it disturbs their academic activities in support of their learning achievement.

\section{REFERENCES}

[1] Nowland, R., Necka, E.A., Cacioppo, J.T. (2018). Loneliness and social internet Use: Pathways to reconnection in a digital world? Perspectives Psychological Science, 13(1): 70-87. https://doi.org/10.1177/1745691617713052

[2] Asongu, S.A., Anyanwu, J.C., Tchamyou, V.S. (2019). Technology-driven information sharing and conditional financial development in Africa. Information Technology for Development, 25(4): 630-659. https://doi.org/10.1080/02681102.2017.1311833

[3] Rahim, R., Dewi, S., Zamroni, M., Lestari, L.P., Nizarudin Wajdi, M., Gunawan, G., Sugiarto, I., Yulius, R., Yuniningsih, Y., Alanda, A., Nasution, M.I. (2018). Pest plant disease prevention and identification system using certainty factor method. International Journal of Engineering and Technology (UAE), 7: 763-65.

[4] Paunov, C., Rollo, V. (2016). Has the internet fostered inclusive innovation in the developing world? World Development, 78: 587-609. https://doi.org/10.1016/j.worlddev.2015.10.029

[5] Sediyono, A., Ariwibowo, A. (2017). Software requirement specification of intelligent system for monitoring and preventing smartphone addiction. 2017 International Conference on Smart Cities, Automation \& Intelligent Computing Systems (ICON-SONICS), Yogyakarta, Indonesia, pp. 54-58. https://doi.org/10.1109/ICON-SONICS.2017.8267821

[6] Karaca, S., Karakoc, A., Gurkan, O.C., Onan, N., Barlas, G.U. (2020). Investigation of the online game addiction level, sociodemographic characteristics and social anxiety as risk factors for online game addiction in middle school students. Community Mental Health Journal, 56: 830-838. https://doi.org/10.1007/s10597019-00544-Z

[7] Juliantari, N.K., Sudarsana, I.K., Sutriyanti, N.K., Astawa, I.N.T., Putri, I.D.A.H., Saddhono, K. (2018). Educational games based in information technology as innovation evaluation activity in learning. Journal of Physics: Conference Series, 1114(1): 12041. https://doi.org/10.1088/1742-6596/1114/1/012041

[8] You, S., Kim, E., Lee, D. (2017). Virtually real: exploring avatar identification in game addiction among massively multiplayer online role-playing games (MMORPG) players. Games Cult., 12(1): 56-71. https://doi.org/10.1177/1555412015581087

[9] Xu, Z., Turel, O., Yuan, Y. (2012). Online game addiction among adolescents: Motivation and prevention factors. European Journal of Information Systems, 21(3): 321-340. https://doi.org/10.1057/ejis.2011.56

[10] Faisal, A. (2020). Antecedent of online buying behavior. Indonesian Management and Accounting Research, $18(2)$ :

1-104. http://dx.doi.org/10.25105/imar.v18i2.3873
[11] Yanti, N.F., Marjohan, M., Sarfika, R. (2019). Tingkat adiksi game online Siswa SMPN 13 Padang. Jurnal Ilmiah Universitas Batanghari Jambi, 19(3): 684-687. https://doi.org/10.33087/jiubj.v19i3.756

[12] Masud, M.M., Ahmed, S., Rahman, M., Akhtar, R. (2016). Measuring psychological effects and internet addiction towards academic performance of tertiary students in Malaysia, International Journal of research in Business and Technology, 9(1): 991-1002. https://doi.org/10.17722/ijrbt.v9i1.465

[13] Higuchi, S., Nakayama, H., Mihara, S., Maezono, M., Kitayuguchi, T., Hashimoto, T. (2017). Inclusion of gaming disorder criteria in ICD-11: A clinical perspective in favor: Commentary on: Scholars' open debate paper on the World Health Organization ICD-11 Gaming Disorder proposal (Aarseth et al.). Journal of Behavioral Addictions, 6(3): 293-295. https://doi.org/10.1556/2006.6.2017.049

[14] Jorge, M.F., Sibilia, P. (2019). The online 'addiction' as a Malaise of the 21 st century: From repression by the law to 'free' unlimited stimulation. The International Journal of Psychoanalysis, 100(6): 1422-1438. https://doi.org/10.1080/00207578.2019.1702882

[15] Guo, Y., Li, T. (2019). Stability analysis of an online game addiction model with relapse and time delay. in Journal of Physics: Conference Series, 1325(1): 12039. https://doi.org/10.1088/1742-6596/1325/1/012039

[16] McEwan, G., Gutwin, C. (2017). A case study of how a reduction in explicit leadership changed an online game community. Computer Supported Cooperative Work (CSCW), 26(4-6): 873-925. https://doi.org/10.1007/s10606-017-9282-0

[17] Liang, C., Wang, S., Chen, R., Zhao, S., Wu, Y. (2020). Research on Ship Electronic Power System Fault Diagnosis Based on Expert System. IOP Conference Series: Materials Science and Engineering, 738(1): 12017. $899 X / 738 / 1 / 012017$

https://doi.org/10.1088/1757-

[18] Sumatorno, I., Arisandi, D., Siahaan, A.P.U., Mesran, M. (2017). Expert system of catfish disease determinants using certainty factor method. International Journal of Recent Trends Engineering \& Research, 3(8): 202-209. https://doi.org/10.31227/osf.io/5xjnz

[19] Pakpahan, A., Sagala, J.R., Yesputra, R., Lubis, A., Saputra, H., Sihotang, H.T. (2019). Implementation of certainty factor method for diagnoses of photocopy machine damage. Journal of Physics: Conference Series, 1255(1): $12059 . \quad$ https://doi.org/10.1088/1742$6596 / 1255 / 1 / 012059$

[20] Slamet, C., Firmanda, B., Ramdhani, M.A., Darmalaksana, W., Enjang, E., Kaffah, F.M. (2019). Android-based expert system design for drug selection using certainty factor. Journal of Physics: Conference Series, 1280(2): 22018. https://doi.org/10.1088/1742$6596 / 1280 / 2 / 022018$

[21] Muludi, K., Suharjo, R., Syarif, A., Ramadhani, F. (2018). Implementation of forward chaining and certainty factor method on Android-based expert system of tomato diseases identification. International Journal of Advanced Computer Science and Applications (IJACSA), 9(9): 451-459. https://doi.org/10.14569/ijacsa.2018.090957

[22] Chang, E., Kim, B. (2019). School and individual factors on game addiction: A multilevel analysis. International 
[23] Azareh, A., Rahmati, O., Rafiei-Sardooi, E., Sankey, J.B., Lee, S., Shahabi, H., Ahmad, B.B. (2019). Modelling gully-erosion susceptibility in a semi-arid region, Iran: Investigation of applicability of certainty factor and maximum entropy models. Science of the Total Environment, 655: 684-696. https://doi.org/10.1016/j.scitotenv.2018.11.235

[24] Saddhono, K., Hasanudin, C., Fitrianingsih, A. (2019). The ability to think creatively on SSCS using schoology Apps, how is the student's language metacognitive awareness? Ingénierie des Systèmes d'Information,

[25] Milani, L., La Torre, G., Fiore, M., Grumi, S., Gentile, D.A., Ferrante, M., Miccoli, S., Di Blasio, P. (2018). Internet gaming addiction in adolescence: Risk factors and maladjustment correlates. International Journal of Mental Health and Addiction, 16(4): 888-904. https://doi.org/10.1007/s11469-017-9750-2

[26] Balakrishnan, J., Griffiths, M.D. (2018). Loyalty towards online games, gaming addiction, and purchase intention towards online mobile in-game features. Computers in Human Behavior, 87: 238-246. https://doi.org/10.1016/j.chb.2018.06.002 